\title{
Islam as The State Ideology: Exploring from Gramsci's Notion of Power, Culture and Ideology
}

WAN NORSHIRA WAN MOHD GHAZALI

International Islamic University Malaysia

\begin{abstract}
The paper aims at establishing relationships between culture, power, and the state ideology. The reading of Malaysian politics through Gramsci's conceptual framework provides a tentative interpretation on the state's exercise of power with popular consent, the structure of power, relation between the state and subaltern groups. Reading through the concept of hegemony, the paper explores the construction and enactment of Islam by the power of the state. It highlights how Islam came to be constructed as the state ideology and how the state establishes and maintains the hegemonic position. On this basis, Islam has been used to produce a specific set of structures in Malaysia to gain national-popular support. The state-society relations will be explored through Gramsci's notion of civil society to illustrate the possible resistance to the state power. The paper suggests that civil society as a field of contestation in Malaysia. The 14th General Election result has demonstrated that ideology could be contested, hence challenging the state's domination or coercive power. In conclusion, this paper has demonstrated the previous state's struggle with civil actors in dominating and maintaining its popular ideology. It could be seen how actors of nonconformist voices in civil society have mobilised themselves into organised groups and institutions to undermine the state hegemony thus assisting the change of the ruling power in the GE14. After 61 years of Independence, Malaysia is finally celebrated the new ruling party.
\end{abstract}

Keywords: Civil society, culture, ideology, power, state hegemony.

\section{INTRODUCTION}

Antonio Gramsci's conceptual framework provides a tentative interpretation on the state's exercise of power with popular consent and the relation between the state and subaltern groups. With Islam as signifying practices, this paper will illuminate the relationship between culture, power, and the state. Reading through the theory of hegemony, it explores the construction, enactment and maintenance of Islam as the state ideology. The current political landscape further shows that the state power could be challenged and the collective will or the popular beliefs of the masses could be raised in the hegemonic political strategy that replaces the existing ones.

\section{CULTURE, POWER, RELIGION AND THE STATE}

Cultural studies contend that power is central to understanding a culture. The production of culture is ordinary because people involved, though not all, in the meaning-making process (Williams as cited in Storey, 2010). To safeguard their interests, dominant groups and institutions are highly involved in the cultural construction. Hence, cultural construction is closely linked to power.

Culture is shared when it is meaningfully recognised and experienced in similar ways. Karl Marx offers an illustration to this notion by stating, "[O]ne man is king only because other men stand in the relation of subjects to him. They, on the contrary, imagine that they are subjects because he is king" (1976, p. 149, cited in Storey, 2010, p. 4). In this view, the 
king is something constructed culturally, "gives these relations meaning; and makes them signify, and [...] by signifying in a particular way, they materially organise practice", (Storey, 2010 , p. 4). Outside this relation, the king may not be meaningful.

Based on Gramsci, Leong (1989) summarises "culture is [...] a tussle in which particular ways of life, or representations of those ways of life, are contested and defended, manufactured and resisted, colonised and opposed" (p. 356). "What pass off as "cultural tradition' or the 'significant past' are actually selective tradition" which have gone through a screening process over other practices and meanings that are perceived to be in line with the dominant culture (as cited in Leong, 1989, p. 356). Through meaningful sharing and recognition by people, culture will be created. It can be drawn that culture is not only consisted of shared but also contested meanings.

To forge symbols, beliefs and practices into the dominant culture and to mobilise public sentiment into certain actions, the state should possess prevailing structures of power in the form of dominance and subordination, (Storey, 2010; Leong, 1989). The discussion of power in cultural studies could be located within Marxism. Lukes (1974, cited in Oswell, 2006) claims power refers to someone's capacity and authority to mobilise others. Gramsci is one of the prominent thinkers from the Marxist tradition who has become an important point of reference for the discussion of power and culture. Operating on the terrain of Marxism, his theoretical writing is useful to inform political practice (Hall, 1996). Drawing his conception of power from Machiavelli, Gramsci asserts that the ruling class "must know well how to imitate beasts as well as employing properly human means [in] exercising power" (cited in O'Shannassy, 2008, p. 90). In Gramscian term, power resides in ideology which is exerted by the dominant bourgeois class on the masses (Daldal, 2014). Gramsci uses hegemony to explain the process and structure of power of a state, one of which through the "relations of dominance and subordination", (Storey, 2010, p. 7). In view of this, hegemony should be explored to explain how culture and ideology are constructed and how they come to be accepted as dominant by other groups, such as in conforming to social norms.

The exercise of power could be explored through domination and leadership. Hegemony and domination was derived from Gramsci's historical context and experience during the rise of facism in Italy in the 1920s (1971). There exist two types of power in a state which are related to political society and civil society: coercive power (domination) and directive power (hegemony) (Oswell, 2006). This notion is derived from Gramsci's (1971) assertion below:

...the supremacy of a social group manifests itself in two ways, as 'domination' and as 'intellectual and moral leadership'. A social group dominates antagonistic groups, which it tends to 'liquidate', or to subjugate perhaps even by armed forces; it leads kindred and allied groups (p. 57).

Any class would be able to rule a society either through domination or/and leadership. Gramsci further expounds "there can, and indeed must, be hegemonic activity even before the rise of power, and that one should not count only on the material force which power gives in order to exercise an effective leadership" (p. 59). Hegemony, thus, works by gaining consensus "of the people over which leadership is sought" (cited in Oswell, 2006, p. 45). 
Domination and leading (hegemony) are two different concepts that will help to understand how power could be exercised. Leading is having the hegemonic direction of civil society while domination involves coercion and force. Gramsci (1971) borrows the Machiavellian term of half man, half animal to differentiate between consent and force. Hegemonic consent is, however, intrinsically indefinite. The consent may be broken due to what Gramsci called "'crisis of authority" (1971, p. 275). This occurs when the authority or ruling classes is no longer 'leading' because they lose consensus from the masses. Instead, they are "exercising coercive force" and only dominant (p. 276). In this event, the ruling groups may be dominant without being hegemonic (Ali, 2015).

When the consensus is lost, "the great masses have become detached from their traditional ideologies, and no longer believe what they used to believe" (Gramsci, 1971, p. 276). Ideological hegemony is constructed by finding some values that are perceived agreeable, pleasant, and echo everyday practices (Lears, 1985; O'Shannassy, 2008) and are connected with the working-class culture (Bennett 1986, cited in Oswell, 2006) while also "corresponds to the needs of the productive forces for development, and hence to the interest of the ruling class" (Gramsci, 1971, p. 429). People should be engaged at the level of culture, called national-popular culture (Oswell, 2006) which is defined by Hall as "the actual, grounded terrain of practices, representations, languages and customs of any specific historical society" (1996, p. 439) to construct a popular hegemony. To engage people culturally, the state should be "ethical in as much as one of its most important functions and moral [and] to raise the great mass of the population to a particular cultural and moral level" (Gramsci, 1971, p. 258). This means for the national-popular culture to become hegemonic, it should be ideological or what Gramsci (1971) refers as corresponding to "common sense", "spontaneous" or "the uncritical and largely unconscious way of perceiving and understanding the world" (p. 322) and "fulfil the masses' needs" (Cappuccio, 2012, p.71). The elite ideological discourse should thus be constructed in relation to national popular culture and should not be in opposition to common sense. Ideological hegemony should be put forward before coercive domination. Hegemony is characterised as:

The "spontaneous" consent given by the great masses of the population to the general direction imposed on social life by the dominant fundamental group; this consent is "historically" caused by the prestige (and consequent confidence) which the dominant group enjoys because of its position and function in the world of production (Gramsci, 1971, p. 12).

In this sense, ideology is exercised to gain cultural and ideological consent since it comes with the consent of subordination to the dominant group. It is within this framework that the state "not only justifies and maintains its domination but [also] wins by leadership and authority the active consent of those over whom it rules" (Hall, 1996, p. 429).

The Gramscian term of ideology and power was also developed by Louis Althusser in "Ideology and The State's Ideological Apparatuses" in 1969. Althusser is another well-known thinker who attempts to fuse Marxism and structuralism in the 1960s. Althusser's understanding of the exercise of the state's power through the repressive and ideological state apparatuses corresponds with Gramsci's discussion of the state as political and civil. According to Althusser (2006), repressive state apparatus contains government, police, army, prisons, and courts similar to Gramscian political society that focuses on the exercise 
of coercive force and power over masses. He also recognises the ideological state apparatus which puts forward ideological power as to get consent from the masses.

Although Althusser made this distinction, he, however, argues that repressive state apparatus could not be purely repressive. Similarly, the ideological state apparatus is not purely ideological. "[T] hey also function secondarily by repression, even if ultimately, but only ultimately, this is very attenuated and concealed, even symbolic" (Althusser, 2006, p. 93). Like Gramsci, Althusser accords education and family are the powerful ideological state apparatuses that use ideological power to ensure conformity from the masses (Daldal, 2014). For example, "schools and churches use suitable methods of punishment, expulsion, selection, etc., to 'discipline' not only their shepherd, but also their flocks" (Althusser, 2006, p. 93). Other ideological apparatuses of the state emphasised by him include religion and culture.

The premise of this discussion suggested that state's ideological hegemony could be successfully established if it involves what Gramsci calls the organic ideology (or common sense); organic in the sense it touches "practical, everyday, common sense, and [it] organise[s] human masses and create[s] the terrain on which men move, acquire consciousness of their position, struggle, etc", (Hall, 1996, p. 431). Since consent is not permanent, the ideological elements which are seen useful for the continuation of hegemony should be reproduced. This could be done through culture's institutions of civil society such as family, education, church, and the media (Villanueva, 1992).

Oswell (2006) reminds that the dominated groups should not be viewed as passive or prone to manipulation by the ruling class. Gramsci particularly discusses the issue in the sphere of civil society which is seen as a key site of struggle with the state. This could be further explained through the domain of civil society. Gramsci describes two major superstructural level; on one hand is "the ensemble of organisms" called the "civil society" or "private" and on the other is the "political society" or "the state" (Gramsci, 1971, p. 12). Although civil society is "not outside the domain of the state", it is called private because it is not within the state control (Daldal, 2014, p. 157). The division between state-society could illustrate the level of autonomy exercised by civil society in relation to state.

Leong (1989), for instance, discusses that the state is involved actively in manufacturing and patterning its national culture through national tourism policy. Leong contends that Singapore exercised both the state power as well as "political, moral, and intellectual leadership to forge certain symbols, beliefs and practices" as "a national culture for tourist consumption", (p. 372). Here, tourism refers to culture's institution and is influential in strengthening and maintaining state hegemony by regulating "popular culture to conform [to the] dominant culture" (p. 372). Tourism as claimed by Leong is a site for cultural manipulation to be marketed for economic and nation-building purposes. Employing the 'multiculturalism' model in its tourism strategy, the state selected the tradition of "some ethnic groups and blur[red] other finer distinctions", (Leong, 1989, p. 373). The state's intervention in the culture of the people shows its domination.

In another study, Cappuccio (2012) presents how language has been used as a political instrument through the expression of the elite-constructed ideology to exert power. Based on Gramsci, Cappuccio looks at language as political. He regards a theatre and its dialect as cultural components and cultural vehicles that would represent the community's worldview. He argues that a theatre served as a social, political, and cultural means for the institution of domination by bourgeoisie class over proletariat groups (Cappuccio, 2012). However, in contrast to Gramsci, Cappuccio focuses on the use of dialect 
in the theatre as a tool to resist the dominant bourgeois culture by maintaining "its individuality and deepe[ning] its position of contrast to dominant views" (p. 80).

Hilley (2001) equally shows Mahathir Mohamed, the fourth and the seventh Prime Minister of Malaysia, had developed a consensual form of hegemonic support as opposed to coercive means using the language of post-ethnic nationalism in Malaysia. Hilley contends:

....as a condition of the rapid economic transition and 'accommodation' of globally ascendant neo-liberal practices in Malaysia in the early 80s, a newly evolved set of state-class relations had begun to unfold, setting in motion social tensions that came to require a more hegemonic form of authority with which to sustain it (p. 7).

Hilley adopts the Gramscian viewpoint and portrays how national-populist outputs such as media stories, academic dialogues, or political account carried hegemonic purposes within them. The examination illuminates the reproduction of a language of power to maintain state hegemony. Hilley also explores one of the dominant counter-hegemonic projects known as vision Islam by the opposition party Parti Islam SeMalaysia (PAS). He illustrates how modernist project by the state acted to mobilise Islamic consciousness in respond to PAS counter-hegemonic project. Hilley observes Mahathir's hegemony has been largely challenged since the beginning of Anwar's affair, the then deputy Prime Minister who was sacked for several allegations. However, he acknowledges it is difficult to displace Mahathir's hegemony due to the absence of a strong opposing populist agenda.

Referring to the main discussion in this section, the debates so far have explored the theoretical insight on the relationship between culture, power, and the state. Hegemony could be argued as providing a source of power for the state to forge ideological and cultural beliefs, practices, and symbols. It has been shown how power resides within ideology. Discussion based on Gramsci has revealed how hegemony is ideologically established in society since power is based on consent to ensure subordination.

The next section will explore how Islam has become the state's enactment or ideology that produces a specific set of hegemonic structures in order to create a particular kind of society. It also explores events leading up to the construction of the Malay-Muslims hegemonic position. Several examples will be examined to illustrate how the government maintains its hegemonic position.

\section{ISLAM AS THE STATE IDEOLOGY}

Religious discourses have raised attention in understanding of how religion becomes part of social and cultural life. Religion is a cultural form that expresses the meaning of life and lived out by social groups. The perspective of cultural studies allows the examination of the dynamic interaction between Islamic belief and practices with social, economic, political, and historical factors. It permits the understanding of the role of Islam in societies by regarding belief and practices as productive phenomena that are regularly shaped by a particular state of affairs.

Religion could be suggested as a key site of an ideological struggle in Malaysia. It could be argued that the government attempts to forge Islamic values and ideas as a dominant ideology since Islam has been perceived to provide a catalyst to strengthen the state's power. Through the notion of hegemony, this section will illustrate how the 
dominant ideology of Islam has gained popular consent and why Islam is so pervasive in the practices of people.

Islam is practically conceptualised in various ways largely in any study of the Muslim community (Eickelman, 1981). Due to the complexity of the position of Islamic practices, there is an ambiguity around the political position of Islam in Malaysia. Azim (2011) claims that the world has witnessed the strong public presence of Islam especially its resurgence in the political sphere. Islam has since become a central stage in political debates. It has made a strong cultural impact on individual lives in societies where the religion plays a dominant role. Azim (2011) argues that on one hand, Islam is lived as a policy, becomes part of the state, and is being raised in political discourse. On the other hand, Islam makes an indirect impact such as on culturally defined codes that regulate activities.

According to Pew Research Center published in April 2017, Islam is one of the world's fastest growing religions, which grows more than twice as fast as the overall world population between 2015 and 2060 (Lipka \& Hackett, 2017). Southeast Asia is one of the most populous Islamic regions in the world (Houben, 2003). The spread of Islam is a great cultural experience in Southeast Asian history. It travels to Southeast Asia through trading and reaches the Malay region through Muslim merchants. Scholars were inconclusive as either Arabian, Persian, or Indian traders who first brought Islam to the Malay Peninsula (Shamsul, 2005). But they agreed that these merchants had established crucial contact with the Malay Peninsula ruling classes and had them reverted to Islam. For this reason, Islam has significantly influenced the cultural practices of the inland people.

The universal phenomenon of Islamic revivalism which begins in the 1970s (Stivens, 2006, cited in Hearman, 2013) brought a wave of religious awareness in Malaysia (Che Soh as cited in Neo, 2006). Islamic revivalism has been seen as a result of the decline of morality in politics, economic, and social continuums. It is one of the most commonly termed events to indicate the widespread of Muslims involving in Islamic movements (Nagata, 1980). Rusnak (2012) suggests that Islamic revivalism is marked through the "growing religious identification and piety by people of all generations and backgrounds" (p. 21). Houben (2003), however, argues that to claim religion was on the decline for it to revive is unfounded. He suggests the growing of Islamic awareness became "more publicly visible and articulate" as Southeast Asian countries went through a process of modernisation ( $p$. 163). Therefore, this paper defines Malaysian revivalism as pushing for a greater role of Islam.

It is vital to note that Islamic revivalism differs from one country to another according to its social, political and economic diversity. Islam has a transnational character that transcends ethnic, cultural, and national barriers which could be found on faith and its sacred sources that promote unity (Anderson, 1983 as cited in Martin, 2014). Since national unity has been a struggle within a pluralistic society of Malaya (Shamsul, 1996) Islam has been viewed to provide a catalyst to protect Malay identity (Rusnak, 2004) and to address racial and social segregation caused by the British colonialism. The Islamic values embraced by the mass Malay during British colonialism facilitated towards tolerant attitudes. Yaapar (2005) claims that the Malay value system which was largely forged by Islam prompted Malays into accepting and accommodating non-Malays.

This paper argues that the government embedded the Islamic values within the fabric of the society with the support of the majority of Muslims. As the government saw the potential of Islam, its values and ideals have been indigenised and promoted in eliteconstructed ideological discourse. From Gramsci's hegemony, consent on Islamic ideology 
occurs as Islamic values have been the tradition of most people in Malaysia since independence. This is true in view of Ong's (1990) argument that "Islamic revivalism reveals itself to be an ideology of the middle[-]class brought into being by state policies" (p. 258).

The post-independence of Malaysia held stronger Islamic values especially during Mahathirism, particularly when he was the fourth Prime Minister of Malaysia, at both social and political levels. With regards to Gramsci's hegemony, the Islamic ideal has been adopted and adapted as the state hegemonic ideology to ensure consent from the masses. Oswell (2006) emphasises for the government to be in a continuous control, it must not only secure the governmental and political institutions, but also "to have the hegemonic direction of civil society", (p. 44) in other words, their consent. This means, hegemony should be actively maintained.

Hegemony is further strengthened through negotiation. For example, the state only promotes values and ideas that seem to concur with and link to the culture of the majority (Oswell, 2006). Hegemony as the exercise of power with popular consent has been displayed by the Malaysian state through its Islamic campaign. The construction and dissemination of intellectual discourse and information are increasingly vital for social control, ideological persuasion, and hegemonic legitimation.

National-popular is a key component that should be incorporated in the ideological discourse in establishing popular hegemony. Consent should be produced and reproduced by the hegemonic ruling group to promote the national-popular. Several important bodies have been called upon to support the state in reproducing dominant interest, ideas, and ideological persuasion. This could be manifested in the form of laws, regulations and outright suppression of any dissenting views (O'Shannassy, 2008).

Let us consider about the role of media to disseminate the state ideology. The state controls media discourse in the form of concentrated ownership where various media being owned by the same few actors such as the Barisan Nasional (BN) component parties or people affiliated with the ruling coalition. The concentration of ownership and consolidation apply to all the Malay, Chinese, and Indian press. When the media is controlled by BN component parties, such as the United Malaysia National Organisation (UMNO), Malaysian Chinese Association (MCA), and Malaysian Indian Congress (MIC), the media tend to be initiated through decisions made by the government alliance instead of through an Act of Parliament (Nain \& Anuar, 1998). The control is also exhibited in the narrow tailoring of media policy (George, 2003) to assist in the production of a specific national-popular culture and ideology. In 1988, for example, the Ministry of Information announced that Radio and Television of Malaysia should carry Islamic contents (Buyong \& Ismail, 2011) by introducing a specific guideline. The guideline has popularised Islamic-driven contents on television and radio programmes. The aim is to subtly promote the view that Islam is dominant over other religions in Malaysia.

Hegemony in Malaysia also involves the coercive exercise of power. As proposed by Gramsci, domination is different from consent when the state is not leading society through consent but coercive domination (1971). Although many have argued the exercise of power over media has halted the freedom of expression (e.g.: Mohd Sani, 2004; Wang, 1998; Heufers, 2002; George, 2003; George, 2007; Kenyon \& Marjoribanks, 2007; Anuar, 2005; Crouch, 1996), the government has often rationalised it is essential to avoid journalists and reporters from provocative reporting that deviates from a dominant national-popular ideology. The exercise of coercive legislations is evidenced in the case of Johan Jaafar, the 
Malay-language daily newspaper's editor of Utusan. He was forced to resign in 1998 after his story was perceived as undermining the image of the Malay leading party, UMNO.

The examples illustrate dominance without being hegemonic. As discussed by Gramsci (1971, p. 57), hegemony involves both consent to "intellectual and moral leadership" and forces of "domination". Hegemony needs to be positively managed and actively constructed. As shown, the media has been employed as a hegemonic cultural institution to create in the minds of the people that the government is the moral authority. This is implemented by managing and keeping the media discussion within a controllable space. The key to this exercise is to embed the popular ideology of the state in the media output to be represented as a social reality. Ideology in a broad sense, helps to reproduce "social domination, [...] legitimate[s] rule by the prevailing groups over subordinate ones, and [...] replicate[s] the existing inequalities and hierarchy of power and control (Durham \& Kellner, 2009, p. xiv). But to regard the complete powerlessness of the media is contestable since public dissenters have become more vocal in demanding the media to be more accountable when it comes to the public interest.

This part illustrates the creation, recreation, and maintenance of the state ideology through Gramsci's conception of hegemony. The Malay Muslim's hegemonic position was established by the state to ensure their cultural and political supremacy above other ethnicities. So far, the discussion reveals hegemony in Malaysia is not only maintained through the exercise of intellectual and moral leadership but also domination as explained by Gramsci (1971).

\section{HEGEMONY AND THE POWER CONTESTATION IN CIVIL SOCIETY}

This section will discuss civil society as the primary site for counter-hegemonic project to illustrate state's hegemonic structure could be resisted and contested. Gramsci provides a useful framework to understand state-society relations. Gramsci urges that hegemony has no longer been able to brainwash people since they are not passive receivers of hegemonic ideals. People are capable to revolt, think critically, and explore their deep-seated belief, hence moving from a mere acceptance of preconditioned ideas. According to Gramsci, state hegemony may be resisted in the context of a civil society which serves as an arena where contest could take place outside the sphere of the state's control.

This paper defines civil society as "an autonomous, self-organised public and multiple forms of civic initiative which are enabled largely by democratic space guaranteed by a constitution" (Martinez, 2004, p. 27). It provides a means to influence public policy production and employment. Drawing from Gramsci, Ramasamy (2004) explains that civil society could be perceived as a site of inequality and contestation between the forces of hegemony and counter-hegemony. The contestation is described in terms of the state's struggle to dominate popular values, norms, and ideas from other actors. Since civil society could cause radical social transformations (Landau, 2008), hegemony should be constructed and reconstructed over civil society to manufacture consent for political domination.

Gramsci's theory helps to illustrate important aspects of civil society and to understand the dynamics of state-society relations in Southeast Asia. Viewing state and civil society in positive terms, Ramasamy (2004) highlights that there is an "integral relationship between both in the enforcement of domination", (p. 203). Landau (2008) claims that some civil society showed their preferences to state interests instead of opposing them. Civil society has played multiple roles among others to serve as a welfare-oriented group to provide aids to the vulnerable (Miles \& Croucher, 2013), to check on the power use of the 
dominant state (Ramasamy, 2004), and to work as activist vehicles that monitor human rights and challenge the political agenda of the government.

The composite structure of, and the interactions between diverse colonial histories, ethnicities, religions, cultures, economic development, and state regimes of countries in Southeast Asia lead to the formation of the antagonist civil society (Guan, 2004). In the 1970s, Guan (2004) explains, civil society was perceived as a threat to the state because it served as a means of self-organisation for citizens in Vietnam, Malaysia, Cambodia and Laos. 'A war of position' is a term used by Gramsci (1971) to refer to this mobilisation which "demands enormous sacrifices by infinite masses of people" (p. 238). Links between oppositional group are developed and their disparate notion of the opposition are forged coherently into "'counter-hegemonic' politics" to protest the existing elite power (Miles \& Croucher, 2013, p. 416). Civil society is thus organised bodies and institutions that contest state hegemony.

The postulation of contestation in civil society against the state hegemony could be seen interpreted in different ways. For example, Holliday (2016) analyses how the subaltern group of the Islamic Republic of Iran was successful in "overthrowing the state hegemon[y] and establishing themselves as the hegemon[y]", (p. 918). The success was largely contributed by combining the populist discourse of Ernesto Laclau and the national-popular collective will of Gramsci. Ernesto Laclau is one of the most important theorists of the "postMarxism" position and a well-known analyst of populism (Stavrakakis \& Galanopoulos, 2018). His idea on populism was devoted in two of his books, "Politics and Ideology in Marxist Theory" published in 1977 and "On Populist Reason" published on 2005. Based on Laclau's populist discourse, 'the people' should be constructed as a political actor or should be taken as a popular subject. The construction of the people as the 'self' also means that people were the important component of the Islamic Revolution and the Islamic Republic. By constructing 'the people' as the 'self', the Islamic Republic of Iran is in antagonism with the Pahlavi regime of the hegemonic 'other'.

The populist discourse became the national-popular collective will that eventually helped the subaltern group challenged the existing hegemony. 'Will' from Gramscian term is "the basis of all political action and can be meaningful when it is the will of the many or in other words, the collective will" (Daldal, 2014, p. 151). The collective will or the popular beliefs of the masses were raised in the hegemonic political strategy (Hall, 1996) in this respect the appointment of Rouhani as a candidate to restore the Islamic Republic regime's legitimacy. Rouhani is considered as the mandate from the above because he was selected by the former president to represent the regime to contest in 2013 election. He also represented a popular will since he won a popular mandate and was elected as a president. The Islamic Republic continued to portray themselves as subalternity and holder of 'the national-popular collective will'. The close relationship between the ruler and the ruled, that the ruler is particularly selected and chosen by the people for the people, has been one of the contributing factors for this success (Holliday, 2016, p. 917).

Meanwhile, Landau (2008) draws upon Gramsci's work to explore the potential of civil society in Cambodia and Vietnam as a field to contest dominant values and ideologies. Landau (2008) reports that civil society in Cambodia could turn into fierce contestation and violent struggles between other social actors and states. For example, journalists must be cautioned not to criticise top government leaders since brutal action may be used against them including killing. Similarly, in Vietnam, several civil organisations have been 
suppressed for voicing out dissenting views against party policies or being perceived to pose political opposition. Consequently, civil society in Vietnam is not commonly viewed to pose challenges or criticisms, but to support the state.

Landau (2008) examines Gramsci's theoretical framework in relation to Vietnam's situation that "the broadening of the political space is likely to come from changes within state institutions, rather than from the rise of an assertive civil society as imagined in the west" (p. 253). Landau (2008) concludes that Gramsci's theoretical framework is limited in explaining Vietnam and Cambodia since his civil society is defined as "associatively separate from the state". Whereas, in Vietnam for instance, "the boundaries between state and society are associatively [...] ill-defined and elusive [where] the most important contestations often occur within the state" (p. 254).

Mohamed Osman and Saleem (2016) discuss the role of the Islamic civil society in Malaysia that works to influence an on-going discourse of Islam in politics that shapes the direction of Islam in the country. They suggest that Islamic civil society groups are less likely to resume the ideological objectives of the mainstream Islamic parties. Rather, they remain in the domain of civil society and pursue their own ideological objectives. Mohamed Osman and Saleem (2016) compare today's Islamic civil society with those in the 1980s and 1990s which involved actively with the mainstream political parties. They claim contemporary civil society groups often challenged one another. Hence, civil society is not merely a contest between the state and the civil society groups, but also among civil society actors to dominate popular views and ideas.

Andrew Willford (2007) illustrates a counter-hegemony sentiment in his book which focuses on the revival of Tamil, Hindu ethnic minority as an unwavering and defensive response to the increasingly popular Islamic hegemony in Malaysia. Willford presents how the economic and political marginalisation of the Indian in Malaysia led some sections of its community to revive religiously against the dominant Islamisation programme. For example, through ecstatic religious rituals such as a Thaipusam celebration, they ensured their Tamil identity was best asserted. Within the domain of culture, the minority group displayed their symbolic rejection towards state and elite Islamic ideologies.

Meanwhile, Bersih, a consolidation of 84 non-governmental organisations, has mobilised support from people using mainly the Internet for information dissemination (Radue, 2012). Bersih has drawn supporters from different social classes and groups to express discontent and to challenge the political hegemony. It has spoken on behalf of Malaysians who want a clear and transparent leadership in Malaysia, particularly with regards to elections. The movement has exposed many abnormalities in government's actions. Bersih has assisted in the increase of political awareness among the public and sparked active involvements from the middle age groups of urban population to shape Malaysia's political landscape.

In short, the growing contestation from the civil society which is organised in the form of institutions has posed challenges. The Malaysian state has been in a constant struggle with civil society groups. It is imperative to hold that opposing views in the form of unrelenting grievances and injustices of the voices from below has worked to the disadvantage of the long-established hegemony. 


\section{CONCLUSION}

Overall, the paper helps to understand the social and political roles of Islam that contribute to the rising discussion of religion as a cultural form and as a key site of ideological struggle particularly in Malaysia. The paper explores the extent to which Islam and its norms, values and practices have been embedded within the fabric of Malaysian society and politics and turned into the hegemonic ideology.

In 2008, Malaysia had shifted from a single-party system to a two-party system where the opposition has posed stronger challenges to the state's hegemonic structure. The long-established hegemony of the then ruling coalition was challenged since the 1999 election which witnessed the shift of Malay voters from Barisan Nasional (BN) parties. But, BN managed to regain its credibility among the subaltern group of the Malay population and retreated its losses in the 2004 election by winning 92 percent of the contested seats. This success was argued contributed by the inability of the counter-hegemony of Pakatan Rakyat (PR) in addressing a narrow party interest (O'Shannassy, 2008). "In particular, the PR was unable to manage $\mathrm{BN}$ provocation and contain tensions over the role of religion, which eventually led to the departure of the DAP over the issue of an Islamic state" (O'Shannassy, 2008, p. 96).

However, in the 12th General Election in 2008, the hegemonic legitimacy of the ruling class has been weakened by counter-hegemonic forces (Miles \& Croucher, 2013). The ruling coalition of BN suffered great losses and no longer held the two-third majority in the parliament. Miles and Croucher (2013) argue the defeat was mainly caused by a strong contestation of civil society organisations against the ruling class hegemony. They examine how civil society organisations have been able to forge relationships with one another to explain the extent to which counter-hegemony is being constructed.

Although the BN coalition retreated its losses in the 13th General Election, they lost power in the 14th General Election (GE14) for the first time recently. The GE14 illustrates that the state hegemony could be challenged and led to the winning of Pakatan Harapan $(\mathrm{PH})$. The GE14 result indicates that hegemony is not a passive consent of the masses in Malaysia because it is something to be worked on before effective leadership could be exercised. In view of Gramsci's framework, the "masses have become detached from their traditional ideologies" (Oswell, 2006, p. 45), that is Islamic ideology. The former government has failed to renew, defend, recreate, or even modify its hegemony and failed to gain consensus of the national-popular collective will, thus ending its domination.

It is fair to suggest that the collective will or the popular beliefs of the masses were raised and addressed in the hegemonic political strategy of $\mathrm{PH}$ that worked to their advantage. As Gramsci (1971, p. 57) emphasises, "[a] social group can, and indeed must, already exercise "leadership" before winning governmental power". Indeed, the close relationship between the ruler and the ruled, that the ruler is particularly selected and chosen by the people for the people, has been one of the contributing factors for $\mathrm{PH}^{\prime} \mathrm{s}$ success.

Pakatan Harapan (PH), the new government coalition, is composed of Parti Pribumi Bersatu Malaysia (PPBM), Parti KeADILan Rakyat (PKR), Democratic Action Party (DAP), and Parti Amanah Negara (Amanah). The mergers of these parties could be suggested to have worked as counter-hegemonic forces to bring down the BN coalition. The questions remain, what contributed to the success of PH although the perceived strong coalition of PR was not 
successful in overthrowing BN party in the GE 13? What specific ideology has been used by $\mathrm{PH}$ that corresponds to the collective will of the society?

Based on these discussions, it is apt to suggest that one of the reasons of BN's lost in the GE14 might be due to the party's failure to maintain the exercise of intellectual and moral leadership. Leadership is consent that must be earned. According to Gramsci, hegemony or the exercise of power with popular consent could be established ideologically. Though, as demonstrated, hegemony should be constructed, reconstructed and gained by the government, and this was not fulfilled by BN.

It could be suggested that Islamic Ideology has lost its effectiveness to retain consensus of the society by looking at the swing of the Malay votes from $\mathrm{BN}$ to $\mathrm{PH}$. However, it is too early to draw a conclusion based on the GE14 result. Therefore, future research should address what has shaken the long-lived Islamic ideology? Has BN failed to address the Islamic ideology sufficiently? Are Islamic ideals and values maintained and reconstructed as the current state hegemony? If yes, how does the current leadership address Islam?

In short, this paper has demonstrated the previous state's struggle with civil actors in dominating and maintaining its popular ideology. It could be seen how actors of nonconformist voices in civil society have mobilised themselves into organised groups and institutions to undermine the state hegemony thus assisting the change of the ruling power in the GE14. After 61 years of Independence, Malaysia is finally celebrated the new ruling party.

\section{BIODATA}

Wan Norshira binti Wan Mohd Ghazali is a lecturer at the Communication Department of International Islamic University Malaysia. Her research interests are in journalism, political economy of media, power, ideology, and the state, and culture and media studies. Email: wannorshira@iium.edu.my 


\section{REFERENCES}

Ali, N. G. (2015). Reading Gramsci Through Fanon: Hegemony Before Dominance in Revolutionary Theory, Rethinking Marxism. Association for Economic and Social Analysis, 27(2), 241-257.

Althusser, L. (2006). Ideology and Ideological State Apparatuses (Notes towards an investigation). In A. Sharma \& A. Gupta (Eds.), The Anthropology of the State: A Reader (pp. 86-111). Australia: Blackwell Publishing.

Anuar, M. K. (2005). Politics and the Media in Malaysia. Philippine Journal of Third World Studies, 20(1), 25-47.

Azim, F. (2011). Editorial Introduction: Islam, Culture, and Women. Inter-Asia Cultural Studies, 12(2), 173-175.

Buyong, M., \& Ismail, R. (2011, October). Islamic Programs in Malaysian Free-To-Air Television Channels. Paper presented at the International Conference on Islamic Civilization and Malay Identity. Retrieved from http://irep.iium.edu.my/7554/2/Islamic_Program_in_Malaysian_TV.pdf

Cappuccio, A. D. M. (2012). The Relationship Between Dialect, Theatre, and Power in Antonio Gramsci. The Italianist, 32(1), 67-83.

Crouch, H. (1996). Government and Society in Malaysia. New South Wales: Allen \& Unwin Australia Ptd Ltd.

Daldal, A. (2014). Power and Ideology in Michel Foucault and Antonio Gramsci: A Comparative Analysis. Review of History and Political Science, 2(2), 149-167.

Durham, M. G. \& Kellner, D. M. (2009). Media and Cultural Studies: Keyworks. USA: Blackwell Publishing.

Eickelman, D. F. (1981). The Middle East: An Anthropological Approach. London: PrenticeHall.

George, C. (2003). The Internet and The Narrow Tailoring Dilemma for Asian democracies. The Communication Review, 6, 247-268.

George, C. (2007). Media in Malaysia: Zone of Contention. Democratization, 14(5), 893-910.

Gramsci, A. (1971). Selections from the Prison Notebooks (Edited and translated by Q. Hoare \& G. N. Smith). London: Lawrence and Hishart.

Guan, L. H. (2004). Civil Society in Southeast Asia. In L. H. Guan (Ed.), Civil Society in Southeast Asia (pp. 1-26). Singapore: Institute of Southeast Asian Studies.

Hall, S. (1996). Gramsci's Relevance for the Study of Race and Ethnicity. In M. David, \& K. H. Chen (Eds.), Stuart Hall: Critical Dialogues in Cultural Studies (pp. 411-440). London: Routledge.

Hearman, V. (2013). Sources and Methodologies: History: Southeast Asia. In S. Joseph (Ed.), Women and Islamic Cultures: Disciplinary Paradigms and Approaches: 2003 - 2013 (pp. 177-202). Leiden: Brill.

Heufers, R. (2002). The Politics of Democracy in Malaysia. Asien, 85, 39-60.

Hilley, J. (2001). Malaysia: Mahathirism, Hegemony and The New Opposition. London: Zed Books Ltd.

Holliday, S. J. (2016). The Legacy of Subalternity and Gramsci's National-Popular: Populist Discourse in The Case of the Islamic Republic of Iran. Third World Quarterly, 37(5), 917-933.

Houben, V. J. H. (2003). Islam: Enduring Myths and Changing Realities: Southeast Asia and Islam. The American Academy of Political and Social Science, 588(149), 1-17. 
Kenyon, A. T., \& Marjoribanks, T. (2007). Transforming Media Markets: The Cases of Malaysia and Singapore. Australian Journal of Emerging Technology and Society, 5(2), 103-118.

Landau, I. (2008). Law and Civil Society in Cambodia and Vietnam: A Gramscian Perspective. Journal of Contemporary Asia, 38(2), 244-258.

Lears, T. J. (1985). The Concept of Cultural Hegemony: Problems and Possibilities. The American Historical Review, 90(3), 567-593.

Leong, W. T. (1989). Culture and The State: Manufacturing Traditions for Tourism. Critical Studies in Media Communication, 6(4), 355-375.

Lipka, M., \& Hackett, C. (2017). Why Muslims Are The World's Fastest-Growing Religious Group. Retrieved from http://www.pewresearch.org/fact-tank/2017/04/06/whymuslims-are-the-worlds-fastest-growing-religious-group/

Martin, D. (2014). Gender, Malayness and the Ummah: Cultural Consumption and MalayMuslim Identity. Asian Studies Review, 38(3), 403-421.

Martinez, P. (2001). The Islamic State or The State of Islam in Malaysia. Contemporary Southeast Asia, 23(3), 474-503.

Miles, L., \& Croucher, R. (2013). Gramsci, Counter-Hegemony and Labour Union-Civil Society Organisation Coalitions in Malaysia. Journal of Contemporary Asia, 43(3), 413-427.

Mohd Sani, M. A. (2004). Media Freedom in Malaysia. Journal of Contemporary Asia, 35(3), 341-367.

Mohamed Osman, M. N., \& Saleem, S. (2016, June 10). The Impact of Islamic Civil Society Organisations on Malaysian Islam and Politics. Retrieved from http://www.rsis.edu.sg/wp-content/uploads/2016/04/Malaysia-Update-April2016_Copy_Finalised.pdf

Nagata, J. (1980). Religious Ideology and Social Change: The Islamic Revival in Malaysia. Pacific Affairs, 53(3), 405-439.

Nain, Z., \& Anuar, M. K. (1998). Ownership and Control of the Malaysian Media. Retrieved from http://journals.upd.edu.ph/index.php/kasarinlan/article/download/448/413

Neo, J. L. C. (2006). Malay nationalism, Islamic supremacy and the constitutional bargain in the multi-ethnic composition of Malaysia. International Journal on Minority and Group Rights, 13(1), 95-118.

O'Shannassy, M. (2008). Beyond the Barisan Nasional? A Gramscian perspective of the 2008 Malaysian general election. Contemporary Southeast Asia, 31(1), 88-109.

Ong, A. (1990). Malay Families, Women's Bodies, and the Body Politic in Malaysia. American Ethnologist, 17(2), 258-276.

Oswell, D. (2006). Culture and Society: An Introduction to Cultural Studies. London: Sage Publications.

Ramasamy, P. (2004). Civil Society in Malaysia: An Arena of Contestations?. In H. G. Lee (Ed.), Civil Society in Southeast Asia (pp. 198-216). Singapore: Institute of Southeast Asian Studies.

Rusnak, T. (2012). Islam, Nationalism, and Nation-Building in Malaysia and Indonesia: Topdown or Bottom-up. McGill International Review, 2(2), 16-22.

Shamsul, A. B. (1996). Debating About Identity in Malaysia: A Discourse Analysis. Southeast Asian Studies, 34(3), 566-600. 
Shamsul, A. B. (2005). Making Sense of the Plural-Religious Past and The Modern-Secular Present of the Islamic Malay World and Malaysia. Asian Journal of Social Science, 33(3), 449-472.

Stavrakakis, Y., \& Galanopoulos, A. (2018). Ernesto Laclau and Communication Studies. Oxford Research Encyclopedias.

Storey, J. (2010). Culture and Power in Cultural Studies: The Politics of Signification. Great Britain: Edinburgh University Press.

Villanueva, V. J. (1993). Bootstraps: From an American Academic of Colour. America: National Council of Teachers of English.

Wang, L. K. (1998). Malaysia: Ownership as Control, Development Dialogue. The Journal of the Dag Hammarskjöld Foundation, 2, 61-84.

Willford, A. C. (2007). Cage of Freedom: Tamil Identity and The Ethnic Fetish in Malaysia. Singapore: NUS Press.

Yaapar, S. (2005). Negotiating Identity in Malaysia: Multi-cultural Society, Islam, Theatre and Tourism. Asian Journal of Social Science, 33(3), 473-485 